\title{
Normal and Reversed-Phase HPTLC Methods for Simultaneous Estimation of Telmisartan and Metoprolol Succinate in Pharmaceutical Formulation
}

\author{
Prajakta S. Nawale, Atul A. Shirkhedkar, Sanjay J. Surana, and Amod S. Patil \\ Department of Pharmaceutical Chemistry, R. C. Patel Institute of Pharmaceutical Education and Research, \\ 425405 Shirpur, Maharashtra, India \\ Correspondence should be addressed to Atul A. Shirkhedkar, atulshirkhedkar@rediffmail.com
}

Received 23 August 2011; Accepted 13 September 2011

Academic Editors: T. Bolanca, R. K. Jyothi, T. Macko, and W. Misiuk

Copyright (C) 2012 Prajakta S. Nawale et al. This is an open access article distributed under the Creative Commons Attribution License, which permits unrestricted use, distribution, and reproduction in any medium, provided the original work is properly cited.

Two simple precise normal-phase (Method I) and reversed-phase (Method II) HPTLC/densitometry method have been developed for simultaneous determination of telmisartan and metoprolol succinate in bulk and in combined tablet formulation. Method I was developed with aluminium plates precoated with silica gel $60 \mathrm{~F}_{254} \mathrm{~S}$, and toluene: propanol: methanol: triethylamine $(8: 1: 1: 0.5$ $\mathrm{v} / \mathrm{v}$ ) was used as as mobile phase. Method II was carried out using aluminium coated with RP-18 silica gel $60 \mathrm{~F}_{254} \mathrm{~S}$ HPTLC plates using methanol: water : triethylamine $(6: 4: 0.5 \mathrm{v} / \mathrm{v})$ as mobile phase. Both analyses were scanned with a densitometer at $242 \mathrm{~nm}$. In Method I, good separation and resolution of drugs were achieved with $R_{f}$ values $0.45 \pm 0.02$ (telmisartan) and $0.70 \pm 0.02$ (metoprolol), while in Method II, telmisartan and metoprolol showed $R_{f}$ values $0.55 \pm 0.02$ and $0.41 \pm 0.02$, respectively. These methods can be used in routine pharmaceutical analysis.

\section{Introduction}

Telmisartan (TELMI), 4' $4^{\prime}$ - $\left(1,4^{\prime}\right.$-dimethyl-2' -propyl $\left[2,6^{\prime}\right.$ bi-1H benzimidazole]-1'-yl) methyl]-[1,1'-biphenyl]-2-carboxylic acid, is an angiotensin II antagonist used as antihypertensive agent [1]. TELMI blocks the vasoconstrictor and aldosterone secreting effects of angiotensin II by selectively blocking the binding of angiotensin II to the AT1 receptor in many tissues, such as vascular smooth muscle and the adrenal gland $[2,3]$. TELMI has been estimated by various methods like spectrophotometric [4], HPLC [5, 6], HPTLC [7-10], and LC-MS [11, 12] in pharmaceutical formulations and biological fluids.

Metoprolol succinate (MET), Bis[(2RS)-1-[4-(2-methoxyethyl)phenoxy]-3-[(1-methylethyl)amino]propan-2-ol] butanedioate, is a cardioselective beta blocker used in the management of hypertension, angina pectoris, cardiac arrhythmias, myocardial infarction, and heart failure [13]. MET has been estimated by spectrophotometric [14], HPLC [15-20], and HPTLC $[21,22]$ methods.
However, there have been no reports concerning the simultaneous determination of TELMI and MET.

In the present work, an effort has been made to estimate TELMI and MET in bulk and in combined tablet dosage form by NP-HPTLC (Method I) and RP-HPTLC (Method II) methods and validated according to ICH guidelines [23].

\section{Experimental}

2.1. Materials and Reagents. Telmisartan and metoprolol were provided as a gift sample by Glenmark pharmaceutical Ltd. Nasik. Drugs were used without any further purification. All other reagents required for experimentation were of analytical reagent (AR) grade. For analysis, toluene, methanol, propanol, and triethylamine were purchased from Merck India.

2.2. Instrumentation and Chromatographic Condition. In Method I, chromatography was performed on $20 \mathrm{~cm} \times 10 \mathrm{~cm}$ 
TABLE 1: Analysis of tablet formulation.

\begin{tabular}{lcccc}
\hline Method & Drug & $\begin{array}{c}\text { Label claim } \\
(\mathrm{mg})\end{array}$ & $\begin{array}{c}\text { \% Amount } \\
\text { found }\end{array}$ & $\begin{array}{c}\text { \% RSD } \\
(n=5)\end{array}$ \\
\hline I & TELMI & 40 & 99.18 & 0.62 \\
& MET & 50 & 99.69 & 0.96 \\
\hline \multirow{2}{*}{ II } & TELMI & 40 & 98.55 & 0.88 \\
& MET & 50 & 99.12 & 0.64 \\
\hline
\end{tabular}

aluminium-backed HPTLC plates coated with $200-\mu \mathrm{m}$ layers of silica gel $60 \mathrm{~F}_{254} \mathrm{~S}$. In Method II, $20 \mathrm{~cm} \times 10 \mathrm{~cm}$ aluminium-backed RP-HPTLC plates coated with $200-\mu \mathrm{m}$ layers of silica gel $60 \mathrm{RP}-18 \mathrm{~F}_{254} \mathrm{~S}$ were used. The plates were washed with methanol before chromatographic measurements and activated at $105^{\circ} \mathrm{C}$ for $5 \mathrm{~min}$. The samples were applied as $6 \mathrm{~mm}$ wide bands with the help of Linomat 5 sample applicator (Muttenz, Switzerland) fitted with a 100$\mu \mathrm{L}$ sample syringe (Hamilton, Bonaduz, Switzerland). The plate was developed in a presaturated Camag twin trough glass chamber $(20 \mathrm{~cm} \times 10 \mathrm{~cm})$. In Method I and Method II, toluene:propanol:methanol: triethylamine $(8: 1: 1: 0.5$ $\mathrm{v} / \mathrm{v})$ and methanol:water: triethylamine $(6: 4: 0.5 \mathrm{v} / \mathrm{v})$, respectively, were used as mobile phases. For Method I and Method II, optimized chamber saturation time was $15 \mathrm{~min}$ and $30 \mathrm{~min}$, respectively. The plates were developed to a distance of $8.0 \mathrm{~cm}$ and scanned densitometrically using Camag TLC Scanner 3 equipped with winCATS software version 1.3.0 at $242 \mathrm{~nm}$ for both methods. The source of radiation utilized was deuterium lamp emitting a continuous UV spectrum between 200 and $400 \mathrm{~nm}$. Evaluation was performed using peak area with linear regression.

2.3. Preparation of Standard and Sample Solutions. Stock standard solution of $1 \mathrm{mg} \mathrm{mL}^{-1}$ of TELMI and $2 \mathrm{mg} \mathrm{mL}^{-1}$ were separately prepared.

2.4. Application of the Proposed Method for Simultaneous Estimation of Both the Drugs in Tablets. Twenty tablets (TELMAXX) were weighed; average weight was determined and then crushed in to fine powder. An accurately weighed tablet powder equivalent to $40 \mathrm{mg}$ of TELMI and $50 \mathrm{mg}$ of MET were transferred to $50 \mathrm{~mL}$ volumetric flask containing $25 \mathrm{~mL}$ methanol and sonicated for $10 \mathrm{~min}$, and volume was adjusted to mark and filtered using $0.45 \mu \mathrm{m}$ filter (Mill filter, Milford, Mass, USA) and $4 \mathrm{~mL}$ of filtrate was further diluted to $10 \mathrm{~mL}$ with methanol. Appropriate volume $4 \mu \mathrm{L}$ was spotted for assay of TELMI and MET. The plates were developed and scanned as described in the above chromatographic conditions in both Method I and Method II (Table 1).

2.5. Preparation of Calibration Curves. From each stock standard solution, 2-8 mL was transferred into two sets of series of seven $10 \mathrm{~mL}$ volumetric flasks, and volume was made up to the mark with methanol. From each volumetric flask, a volume $4 \mu \mathrm{L}$ was applied on HPTLC plate to obtain series of concentration 800-3200 ng per band of TELMI and 1600$6400 \mathrm{ng}$ per band of MET. The plates were developed and

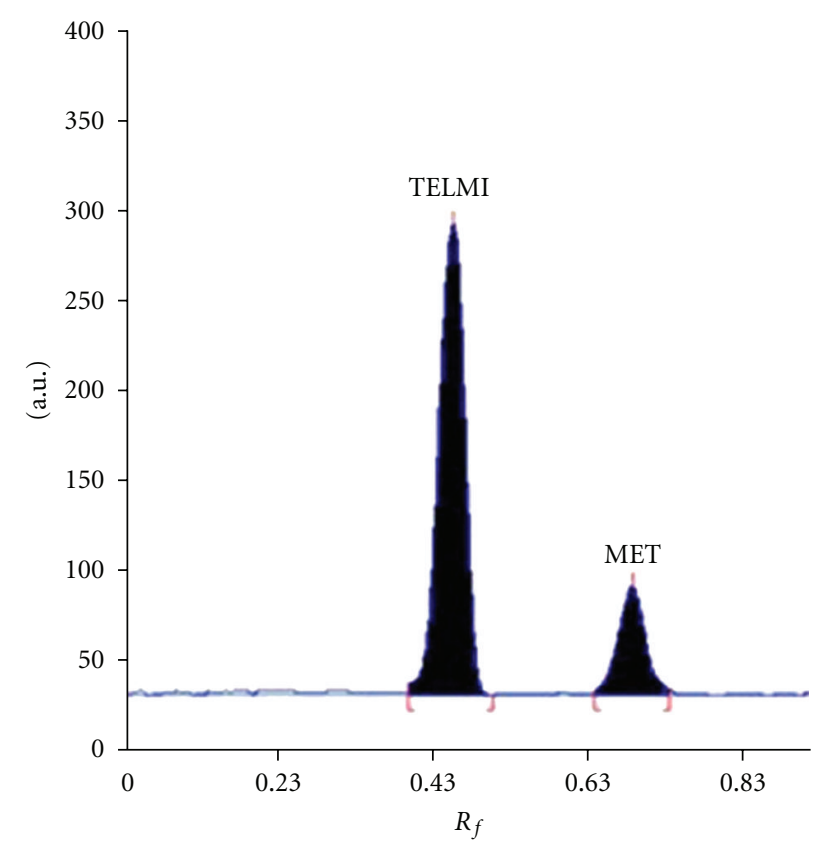

Figure 1: Densitogram of TELMI standard $\left(R_{f} 0.45 \pm 0.02\right)$ and MET standard $\left(R_{f} 0.70 \pm 0.02\right)$ measured at $242 \mathrm{~nm}$.

scanned as described under above established chromatographic conditions for both methods. Each standard in six replicates was analyzed, and peak areas were recorded. Calibration curves of TELMI and MET were plotted separately of peak area versus respective concentration of TELMI and MET.

\section{Results and Discussion}

\subsection{Optimization of HPTLC Method}

3.1.1. Method I. Optimization of mobile phase was done with a view to separate both these drugs. Various proportions of methanol and toluene were tried as mobile phase. When toluene : $n$-propanol : methanol $(8: 1: 1 \mathrm{v} / \mathrm{v})$ was used as mobile phase, both these drugs were resolved from each other, but the tailing was observed. Therefore, to whip the problem triethylamine was added which has improved the spot characteristic. Finally, toluene: propanol: methanol : triethylamine $(8: 1: 1: 0.5 \mathrm{v} / \mathrm{v})$ showed well-defined and resolved peaks when the chamber was saturated with mobile phase for $15 \mathrm{~min}$ at room temperature. Both the peaks were well resolved, and no telling observed when plate was scanned at $242 \mathrm{~nm}$. The $R_{f}$ for TELMI and MET were found to be $0.45 \pm 0.02$ and $0.70 \pm 0.02$, respectively (Figure 1 ).

3.1.2. Method II. Firstly, single solvents were selected on the basis of their polarity to separate the spots. Then, the mixtures of solvents were used for separation purpose of TELMI and MET. The spots were developed in mixtures of methanol and water in the ratio of $3: 2 \mathrm{v} / \mathrm{v}$. The $R_{f}$ value obtained was good, but slight tailing was observed. Hence, to reduce the tailing, triethylamine was added in 
TABLE 2: Recovery studies.

\begin{tabular}{|c|c|c|c|c|c|}
\hline Method & Drugs & Initial amount (ng per band) & Amount added (\%) & $\%$ recovery & $\% \operatorname{RSD}(n=3)$ \\
\hline \multirow{6}{*}{ Method I } & \multirow{3}{*}{ TELMI } & 1400 & 80 & 99.39 & 0.65 \\
\hline & & 1400 & 100 & 99.59 & 0.38 \\
\hline & & 1400 & 120 & 99.66 & 0.28 \\
\hline & \multirow{3}{*}{ MET } & 1750 & 80 & 99.27 & 0.66 \\
\hline & & 1750 & 100 & 99.01 & 0.46 \\
\hline & & 1750 & 120 & 99.00 & 0.52 \\
\hline \multirow{6}{*}{ Method II } & \multirow{3}{*}{ TELMI } & 1400 & 80 & 98.83 & 1.09 \\
\hline & & 1400 & 100 & 99.79 & 0.78 \\
\hline & & 1400 & 120 & 99.57 & 0.39 \\
\hline & \multirow{3}{*}{ MET } & 1750 & 80 & 98.27 & 1.08 \\
\hline & & 1750 & 100 & 99.00 & 0.61 \\
\hline & & 1750 & 120 & 99.00 & 0.65 \\
\hline
\end{tabular}

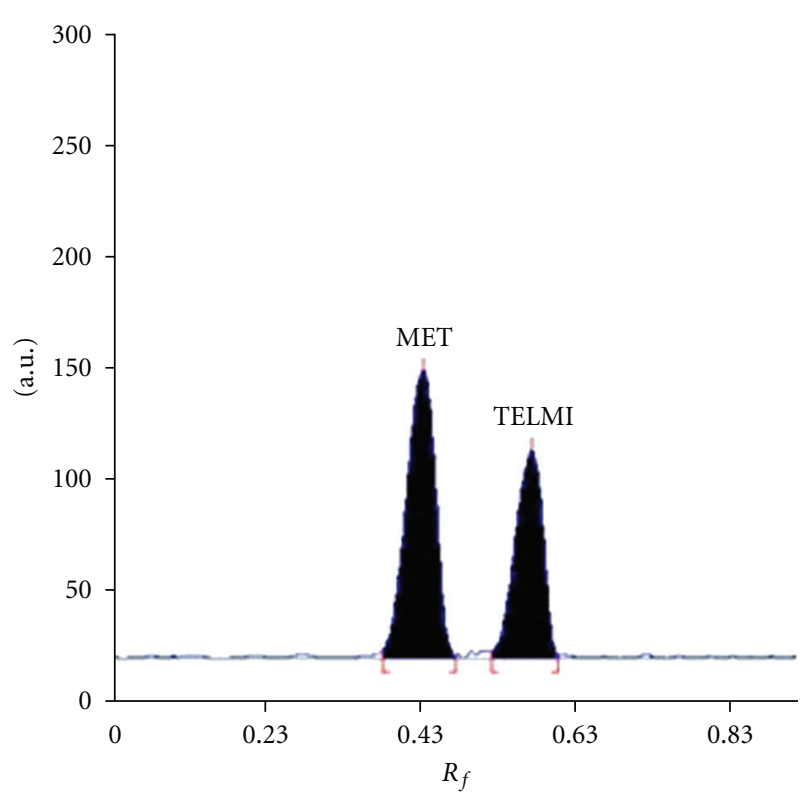

Figure 2: Densitogram of MET standard $\left(R_{f} 0.41 \pm 0.02\right)$ and TELMI $\left(R_{f} 0.55 \pm 0.02\right)$ measured at $242 \mathrm{~nm}$.

the solvent system. Thus, the final mobile phase consisted of methanol: toluene: triethylamine in the ratio $(6: 4: 0.5 \mathrm{v} / \mathrm{v})$. The chamber saturation time was $30 \mathrm{~min}$. The $R_{f}$ for TELMI and MET were found to be $0.55 \pm 0.02$ and $0.41 \pm 0.02$, respectively (Figure 2).

3.2. Validation. The method was validated by establishing linearity, accuracy, interday and intraday precision of measurement of sample application. The limit of detection and limit of quantification were also determined.

3.3. Linearity. Linearity was studied in the concentration range from 800-3200 ng per band for TELMI and 16006400 ng per band for MET for both methods. The drugs showed good linearity in the tested range. The regression coefficient values for TELMI and MET were found to be $r^{2}>0.99$ in both Method I and Method II.

3.4. Accuracy. The accuracy of the experiment was established by spiking preanalyzed sample with known amounts of the corresponding drugs at three different concentration levels, that is, $80 \%, 100 \%$, and $120 \%$ of the drug in the tablet. The spiked samples were then analyzed for three times. The mean recovery is within acceptable limits, indicating both methods are accurate (Table 2).

\subsection{Specificity}

3.5.1. Method I. The specificity of the method was ascertained by analyzing drug standards and sample. The mobile phase resolved both the drugs very efficiently. The $R_{f}$ value of TELMI and MET was found to be 0.45 and 0.70 , respectively. The peak purity of TELMI extracted from tablet and TELMI standard was tested at the peak-start (S), peak-apex (A), and at the peak-end (E) position (Figure 3 ). The peak purity of MET extracted from tablet and MET standard was tested by correlating the spectra's of MET at the peak-start (S), peakapex (A), and at the peak-end (E) positions (Figure 4).

3.5.2. Method II. The mobile phase designed for the method resolved both the drugs very efficiently. The $R_{f}$ value of TELMI and MET was found to be 0.55 and 0.41 , respectively. The peak purity of TELMI extracted from tablet and TELMI standard was tested at the peak-start (S), peak-apex (A), and at the peak-end (E) positions (Figure 5). The peak purity of MET extracted from tablet and MET standard was tested by correlating the spectra's at the peak-start (S), peak-apex (A), and the peak-end (E) positions (Figure 6).

3.6. Ruggedness and Robustness. Ruggedness of the both method was performed for TELMI and MET by two different analysts maintaining similar experimental and environmental conditions. 
TABLE 3: Validation parameters.

\begin{tabular}{|c|c|c|c|c|}
\hline \multirow{2}{*}{$\begin{array}{l}\text { Method } \\
\text { Parameters }\end{array}$} & \multicolumn{2}{|c|}{ Method I } & \multicolumn{2}{|c|}{ Method II } \\
\hline & TELMI & MET & TELMI & MET \\
\hline Linearity (correlation coefficient) & 0.997 & 0.997 & 0.996 & 0.998 \\
\hline Slope & 3.443 & 0.381 & 0.827 & 0.660 \\
\hline Intercept & 2589 & 732.1 & 803.5 & 1135 \\
\hline \multicolumn{5}{|l|}{ Ruggedness (\% RSD) } \\
\hline Analyst-I $(n=6)$ & 0.71 & 1.52 & 0.63 & 0.90 \\
\hline Analyst-II $(n=6)$ & 0.60 & 0.96 & 0.87 & 1.14 \\
\hline \multicolumn{5}{|l|}{ Robustness [\% RSD] $(n=6)$} \\
\hline Mobile phase composition & 0.41 & 0.69 & 0.87 & 0.29 \\
\hline Duration of saturation time & 0.84 & 1.23 & 0.74 & 0.83 \\
\hline Mobile phase volume & 1.49 & 1.05 & 0.43 & 0.43 \\
\hline Development distance & 0.38 & 0.74 & 0.19 & 0.65 \\
\hline \multicolumn{5}{|l|}{ Sensitivity } \\
\hline Limit of detection (ng) & 2.79 & 58.69 & 43.97 & 64.18 \\
\hline Limit of quantitation (ng) & 8.45 & 177.86 & 133.26 & 194.49 \\
\hline \multicolumn{5}{|l|}{ Precision (\% RSD) } \\
\hline Intraday $(n=3)$ & $0.44-0.73$ & $0.62-0.97$ & $0.51-0.67$ & $0.51-1.13$ \\
\hline Interday $(n=3)$ & $0.52-0.89$ & $0.46-1.38$ & $0.56-0.79$ & $0.57-1.23$ \\
\hline Repeatability $(n=6)$ & 0.75 & 1.40 & 1.02 & 0.86 \\
\hline
\end{tabular}

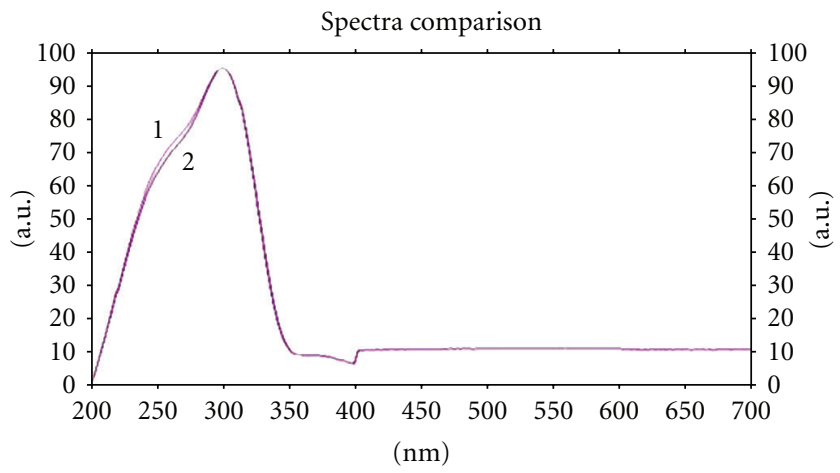

Figure 3: Peak purity spectra of standard 1 TELMI, sample 2 extracted from telmisartan-metoprolol tablet, scanned at the peakstart, peak-apex, and peak-end positions of the band (correlation > 0.99).

Robustness of the method was performed by introducing various changes in the previous chromatographic conditions; effects on the results were examined for both method.

3.7. Sensitivity. The sensitivity of measurements of TELMI and MET by the use of the proposed method was estimated in terms of the limit of quantitation (LOQ) and the lowest concentration detected under the chromatographic conditions as the limit of detection (LOD).

LOQ and LOD were calculated by the use equation $\mathrm{LOD}=3.3 \times N / B$ and $\mathrm{LOQ}=10 \times N / B$, where " $N$ " is standard deviation of the peak areas of the drugs $(n=$ $3)$, taken as a measure of noise, and " $B$ " is the slope of

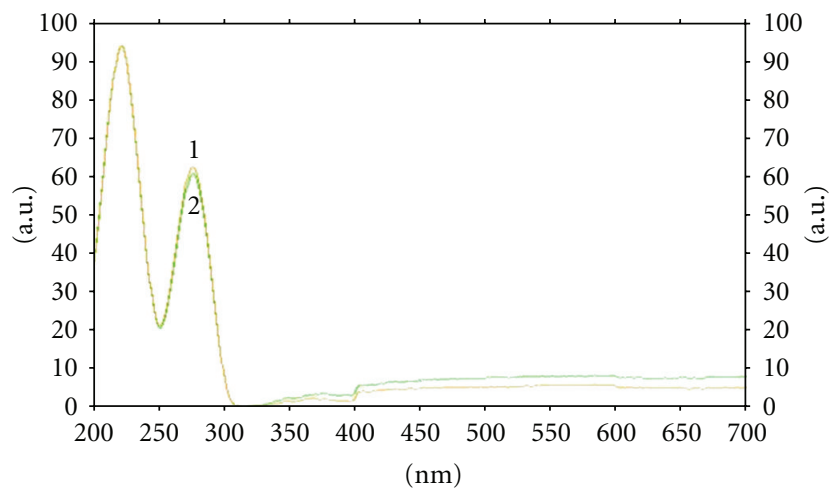

FIgure 4: Peak purity spectra of MET standard 1, sample 2 extracted from telmisartan-metoprolol tablet, scanned at the peak-start, peak-apex, and peak-end positions of the band (correlation $>0.99$ ).

the corresponding calibration curve. The results are recorded for both the methods.

Different validation parameters for the both methods for determining TELMI and MET content were summarized in Table 3.

\section{Analysis of Tablet Formulation}

In Method I, compact spots of TELMI and MET were obtained with $R_{f}$ values 0.45 and 0.70 , respectively. While in Method II, TEMI and MET were well-resolved chromatogram with $R_{f}$ values 0.55 and 0.41 , respectively. In both these methods, good separation and well-resolved spots were 


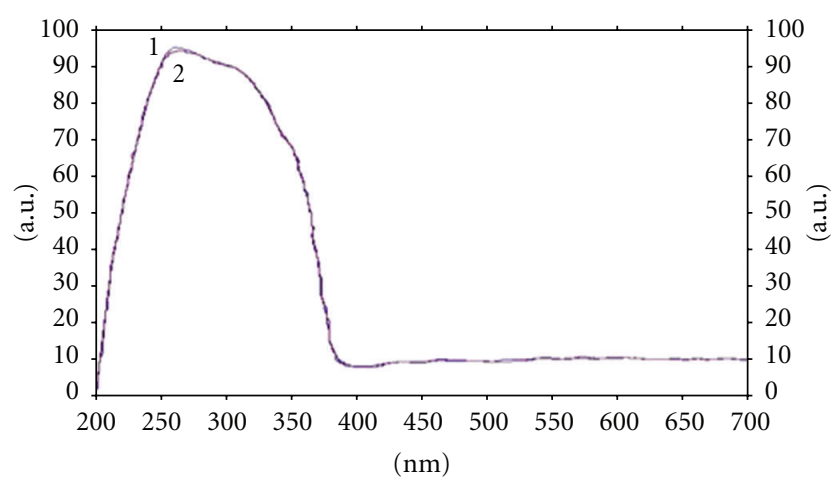

FIGURE 5: Peak purity spectra of TELMI standard 1, sample 2 extracted from telmisartan-metoprolol tablet, scanned at the peakstart, peak-apex, and peak-end positions of the band (Correlation > 0.99).

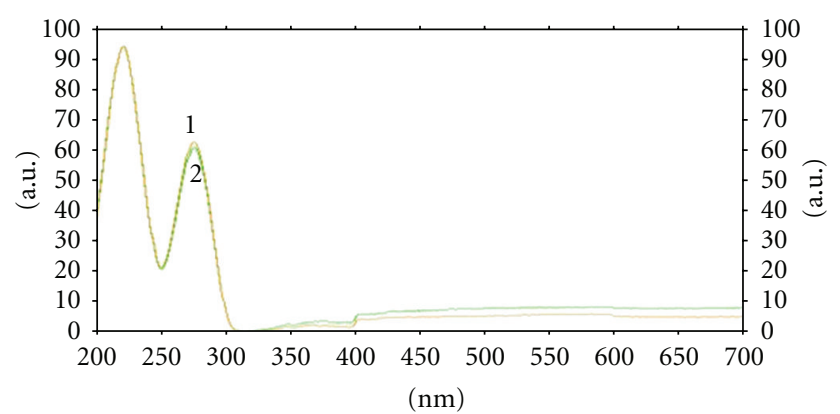

FIgURE 6: Peak purity spectra of MET standard 1, sample 2 extracted from telmisartan-metoprolol tablet, scanned at the peakstart, peak-apex, and peak-end positions of the band (Correlation > 0.99).

obtained, which indicates that there is no interferences commonly present in the tablet formulation.

\section{Conclusion}

The proposed Method I and Method II provide simple, accurate, and reproducible quantitative analysis for simultaneous determination of TELMI and MET in combined tablet dosage form. Both these method were validated according to ICH guidelines.

\section{Acknowledgment}

The authors are thankful to R. C. Patel Institute of Pharmaceutical Education and Research.

\section{References}

[1] The Merck Index, Merck Research lab, Division of Merck and Co. Inc., White House Station, NJ, USA, 14th edition, 2004.

[2] A. K. Muthu, R. Sankhla, S. Gupta, A. A. Smith, and R. Manavalan, "Development and validation of a reversed phase hplc method for simultaneous determination of amlodipine and telmisartan in pharmaceutical dosage form," Journal of Chemical Research, vol. 12, pp. 43-52, 2010.

[3] S. C. Sweetman, Martindale-The Complete Drug Reference, Pharmaceutical Press, London, UK, 35th edition, 2007.

[4] M. S. Palled, M. Chatter, P. M. N. Rajesh, and A. R. Bhat, "Difference spectrophotometric determination of telmisartan in tablet dosage forms," Indian Journal of Pharmaceutical Sciences, vol. 68, no. 5, pp. 685-686, 2006.

[5] C. P. Kishore, V. B. Reddy, and D. M. Kale, "Development and validation of stability indicating HPLC method for the estimation of telmisartan related substances in tablets formulation," International Journal of Research in Pharmaceutical Sciences, vol. 1, no. 4, pp. 493-501, 2010.

[6] A. Gupta, R. M. Charde, and M. S. Charde, "Determination of Telmisartan and forced degradation behavior by RP-HPLC in tablet dosage form," Journal of Pharmacy Research, vol. 4, no. 4, pp. 1270-1273, 2011.

[7] N. R. Vekariya, M. B. Patel, G. F.. Patel, and R. B. Dholakiya, "Development and validation of TLC-densitometry method for simultaneous determination of telmisartan and amlodipine besylate in bulk and tablets," Journal of Young Pharmacists, vol. 1, no. 3, pp. 259-263, 2009.

[8] V. A. Patel, P. G. Patel, B. G. Chaudhary, N. B. Rajgor, and S. G. Rathi, "Development and validation of hptlc method for the simultaneous estimation of telmisartan and ramipril in combined dosage form," International Journal on Pharmaceutical and Biological Research, vol. 1, no. 1, pp. 18-24, 2010.

[9] A. R. Chabukswar, S. C. Jagdale, S. V. Kumbhar et al., "Simultaneous HPTLC estimation of telmisartan and amlodipine besylate in tablet dosage form," Archives of Applied Sciece Research, vol. 2, no. 3, pp. 94-100, 2010.

[10] N. Shah, B. Suhagia, R. R. Shah, and P. B. Shah, "Development and validation of a HPTLC method for the simultaneous estimation of telmisartan and hydrochlorothiazide in tablet dosage form," Indian Journal of Pharmaceutical Sciences, vol. 69, no. 2, pp. 202-205, 2007.

[11] B. M. Chen, Y. Z. Liang, Y. L. Wang et al., "Development and validation of liquid chromatography-mass spectrometry method for the determination of telmisartan in human plasma," Analytica Chimica Acta, vol. 540, no. 2, pp. 367-373, 2005.

[12] H. Zhang and Y. Z. Fang, "HPLC/APCI/MS determination of telmisartan in human plasma," Yaowu Fenxi Zazhi, vol. 24, no. 5, pp. 497-499, 2004.

[13] British Pharmacopoeia, vol. 2, Stationary Office, Medicines and Healthcare Products Regulatory Agency, London, UK, 2005.

[14] K. S. Kumar, R. Ravikumar, A. Rajasekaran, and V. Ravichandran, "Simultaneous spectrophotometric determination of metoprolol tartrate and ramipril," Digest Journal of Nanomaterials and Biostructures, vol. 5, no. 1, pp. 173-176, 2010.

[15] M. M. Rao, S. A. Rahaman, Y. R. Prasad, and P. G. Reddy, "RPHPLC method of simultaneous estimation of amlodipine besylate and metoprolol in combined dosage form," International Journal of Pharmaceutical Research and Development, vol. 2, pp. 69-76, 2010.

[16] S. Chawla, S. Ghosh, V. Sihorkar, R. Nellore, T. R. S. Kumar, and N. R. Srinivas, "High-perfomance liqiud chromatography method development and validation for simultaneous determination of five model compounds, antipyrine metoprolol, ketoprofen, furosemide and phenol red, as a tool for standardization of rat in situ intestinal permeability studies using timed wavelength detection," Biomedical Chromatography, vol. 20, no. 4, pp. 349-357, 2006. 
[17] B. Singh, D. K. Patel, and S. K. Ghosh, "Development of reverse-phase HPLC method for simultaneous analysis of metoprolol succinate and hydrochlorothiazide in a tablet formulation," Tropical Journal of Pharmaceutical Research, vol. 8, no. 6, pp. 539-543, 2009.

[18] B. Yilmaz, S. Arslan, and V. Akba, "Gas chromatography-mass spectrometry method for determination of metoprolol in the patients with hypertension," Talanta, vol. 80, no. 1, pp. 346351, 2009.

[19] M. D. Phale and P. D. Hamrapurkar, "A validated and simplified RP-HPLC of metoprolol succinate from bulk drugs," Asian Journal of Scientific Research, vol. 2, no. 3, pp. 119-122, 2009.

[20] M. Aqil, A. Ali, A. Ahad, Y. Sultana, A. K. Najmi, and N. Saha, "A validated HPLC method for estimation of metoprolol in human plasma," Acta Chromatographica, no. 19, pp. 130-140, 2007.

[21] S. R. Sathe, S. B. Bari, and S. J. Surana, "Development of HPTLC method for the estimation of metoprolol succinate in bulk and in tablet dosage form," Indian Journal of Pharmaceutical Education and Research, vol. 42, no. 1, pp. 32-35, 2008.

[22] C. Prabhu, G. S. Subramanian, A. Karthik, S. Kini, M. S. Rajan, and N. Udupa, "Determination of telmisartan by HPTLC - A stability indicating assay," Journal of Planar ChromatographyModern TLC, vol. 20, no. 6, pp. 477-481, 2007.

[23] ICH, "Q2(R1), validation of analytical procedures: text and methodology," in Proceedings of the International Conference on Harmonization, p. 1, Geneva, Switzerland, 2005. 


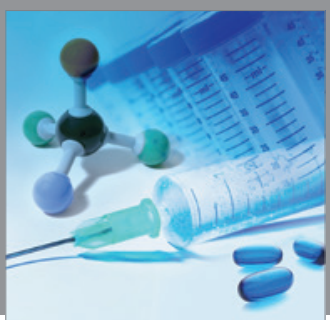

International Journal of

Medicinal Chemistry

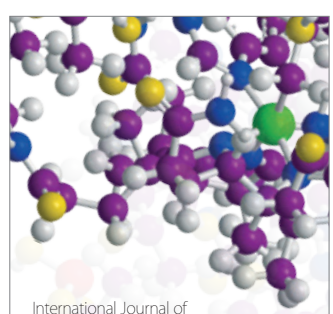

Carbohydrate Chemistry

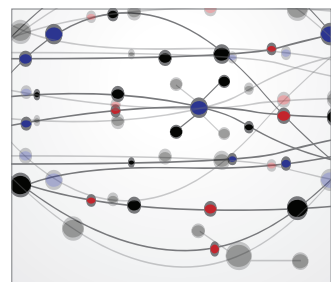

The Scientific World Journal
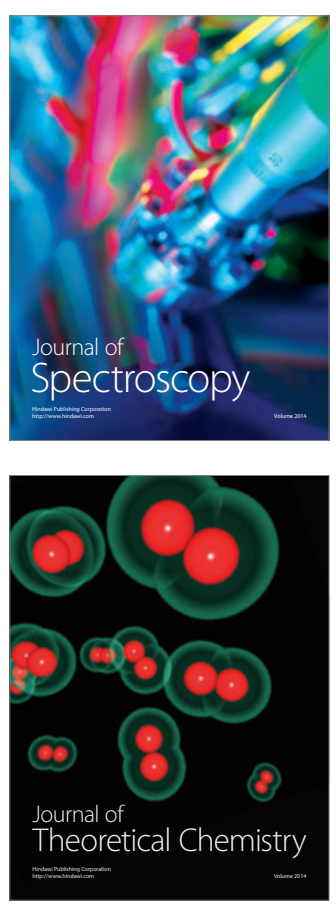
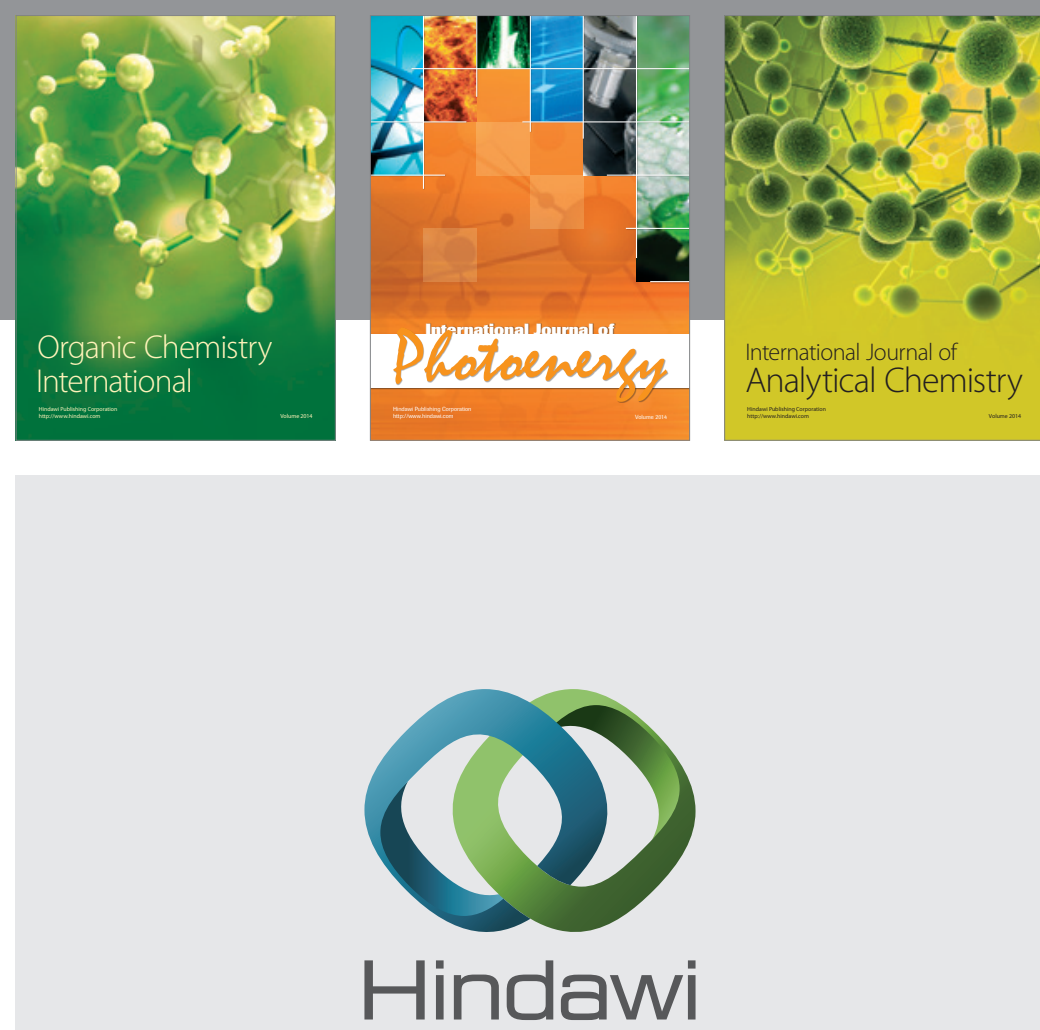

Submit your manuscripts at

http://www.hindawi.com
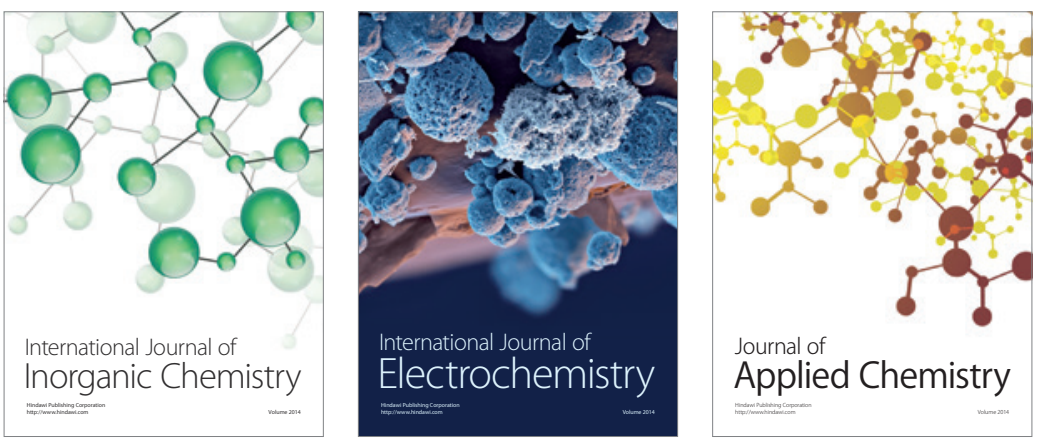

Journal of

Applied Chemistry
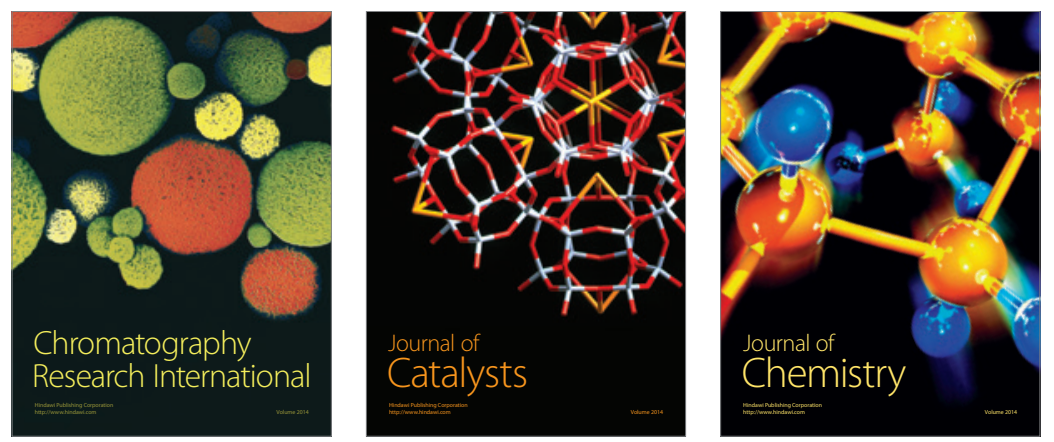
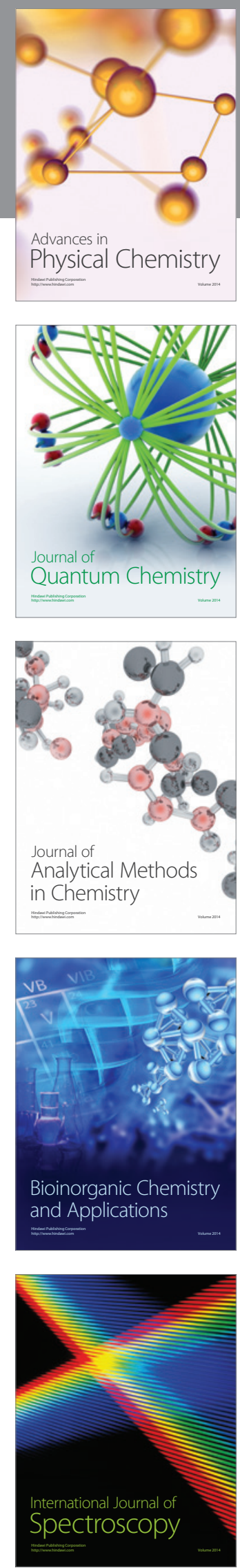